Vida Davidaviciene,

Ph.D., Vilnius Gediminas Technical University, Lithuania

ORCID ID, 0000-0002-0931-0967

email: vida.davidaviciene@vilniustech.It

Jurgita Raudeliuniene,

Ph.D., Vilnius Gediminas Technical University, Lithuania

ORCID ID, 0000-0003-4003-0856

email: jurgita.raudeliuniene@vilniustech.It

Akvile Jonyte-Zemlickiene,

Vilnius Gediminas Technical University, Lithuania

email: akvile.jonyte-zemlickiene@stud.vgtu.It

Manuela Tvaronaviciene,

Ph.D., Vilnius Gediminas Technical University, Lithuania

D ORCID ID, 0000-0002-9667-3730

email: manuela.tvaronaviciene@vilniustech.It

Correspondence author: jurgita.raudeliuniene@vilniustech.It

\title{
FACTORS AFFECTING CUSTOMER BUYING BEHAVIOR IN ONLINE SHOPPING
}

Abstract. Globalization processes rapidly advance information and communications technologies that influence social, economic, and cultural changes and transform consumers' needs and buying behavior in online shopping. Business sector organizations operating in a dynamic environment have to adjust to the environment's uncertainty, consider the changing needs of consumers and find effective and efficient ways to create a unique value for them. However, researchers and business practitioners have different interpretations and assessments of the factors influencing end-user purchasing behavior in the internet space. Therefore, the main problem area is how to assess which approach more comprehensively reflects and conveys the online market reality related to consumer buying behavior. This study examines these issues by combining various researchers' and business practitioners' positions to assess factors influencing consumers' decision-making in online shopping. This study aims to evaluate the critical factors related to e-shop characteristics and the product features that significantly impact consumer buying behavior in online shopping. Scientific literature review showed that the most crucial e-shop characteristics are e-shop design, e-shop informativeness, e-shop convenience, e-shop security, and e-shop popularity. From product features' perspectives, scientists and business practitioners mainly focus on product design and packaging, price, brand, customer reviews, and delivery time. The case study analysis of Lithuanian consumers was chosen for a comprehensive investigation because there is a lack of complex research in Lithuania to identify which factors are the most significant for consumer decision-making in the electronic space. Research methods such as scientific literature analysis, survey (structured questionnaire), correlation, and regression analysis were used to achieve the research goal. The survey results demonstrated that Lithuanian customers prefer traditional shopping compared to online purchases. As a result, the investigation results indicate that online purchases in Lithuania are still a growing market. Depending on survey results, the most crucial e-shop characteristics affecting Lithuanian customer buying behavior in online shopping were identified as e-shop design and e-shop security. Furthermore, the most influencing product features related to customer buying behavior in online shopping were product design and packaging, product price. Correlation and regression analysis proved that significant factors are e-shop design, e-shop security, product design and packaging, product price, and customer reviews for Lithuanian buyers in online shopping.

Keywords: customer buying behavior, e-shop characteristics, product features, online shopping, Lithuania.

Cite as: Davidaviciene, V., Raudeliuniene, J., Jonyte-Zemlickiene, A., \& Tvaronaviciene, M. (2021). Factors Affecting Customer Buying Behavior in Online Shopping. Marketing and Management of Innovations, 4, 11-19. http://doi.org/10.21272/mmi.2021.4-01 
Introduction. Information and communications technologies are becoming increasingly important in society and significantly impact different business sectors and consumer self-determination in the online market (Grewal et al., 2017). Rapid technological development makes it possible to meet the constantly changing consumers' needs in online shopping more effectively and efficiently (Chiabai et al., 2014; Darsono et al., 2019; Javaria et al., 2020; Rezaei et al., 2016). It also poses particular challenges for business organizations seeking to create unique value for consumers by facing environmental dynamics and constraints leading to different forms of risk (Andryeyeva et al., 2021; Cherenkov et al., 2020).

Because of the continuous changes in the online environment, business organizations encounter a diverse goods supply and the impact of various factors related to e-shop and product diversity that strongly influence customers' decision to choose one or another product in a physical store or e-shop. Therefore, the variety of components of the e-shop and the offered product depends not only on the product's final price but also on the consumer's final decision to purchase the product or not. As a result, the impact of both e-shop and product components on the consumer is significant because this combination creates representative, informational, or unique value leading to customer's buying behavior. Based on research results, the overall value offered by product brand, product design and packaging, product price, customer reviews, or product delivery time (Cao et al., 2018; Hussain et al., 2015; Park et al., 2012) becomes essential drivers of online shopping if lack of possibility to inspect the product before purchasing. Besides, most companies invested in e-shop design, informativeness, convenience, security, or popularity to create a unique user experience and value, for instance, by exploring tactile sensations (Overmars and Poels, 2015b; Spence and Gallace, 2011), sensory perception (Krishna, 2012) or creativity aspects (Davidaviciene et al., 2019). However, due to rapidly changing information and communication technologies, business organizations face opportunities and challenges that these technologies create (Rausser et al., 2018; Stefko et al., 2019; Strielkowski et al., 2020). Consequently, there is still a lack of comprehensive research to assess the impact of the e-shop and product components on consumer buying behavior in a virtual environment. Researchers and business practitioners have different perspectives and assessments of the factors influencing end-user behavior in online shopping. This study examines these issues by combining various positions associated with assessing e-shop and product factors affecting consumers' online shopping decision-making.

The purpose of this study is to evaluate the critical factors related to e-shop characteristics and the product features that significantly impact consumer buying behavior in online shopping. The Lithuanian online market case study analysis was chosen because of the lack of complex research in Lithuania about e-shop characteristics and product features that affect consumer buying behavior in the electronic space. Research methods such as scientific literature analysis, survey (structured questionnaire), correlation, and regression analysis were used to achieve the study goal.

Literature Review. Researchers and business practitioners distinguish between different combinations of factors that influence end-users decisions to buy online (Bartikowski and Singh, 2014; Overmars and Poels, 2015a; Simionescu and Strielkowski, 2017; Rahman et al., 2018). One of the main factors is product and packaging design (Dong and Gleim, 2018; Hussain et al., 2015; Kahn, 2017; Rundh, 2013; Wu, 2015; Yu et al., 2018). With a wide range of products supply, every business organization looks for innovative and unique solutions to stand out in the market. One of them is related to product and packaging design solutions. Most researchers emphasized that design is an integral part of a product and packaging. Scientists define design concept broadly when design can be described as a process (designing, modeling), activity outcome, or created value designed to affect the target audience's emotions purposefully (Agariya et al., 2012). Product and packaging design integrates visual, functional, sensory, aesthetic, or informational dimensions (Dong and Gleim, 2018; Hussain et al., 2015; Kahn, 2017; Pieters et al., 2010; Spence and Gallace, 2011). The functional design dimension is related to the product's primary purpose and functional characteristics. The sensory aspect is associated with the user's sensory senses, which help create a unique experience and product value. The aesthetic design dimension is 
related to the aesthetic demonstration of a product and the aesthetic assessment of consumers about the physical parameters of the product. The information dimension is designed to convey consumer-specific information about product unique features. For instance, Pieters et al. (2010) underlined in their study visual complexity the importance of capturing customer's attention, including perceptual features and creative design elements (Pieters et al., 2010). Hussain et al. (2015) conducted a study that looked at product packaging as brand communication with consumers (Hussain et al., 2015). Based on scientific research results, e-shop and product design could be decisive factors influencing the consumer's decision to buy online because it stimulates the consumer's visual perception or tactile sensations, encouraging them to purchase the product (Hasan, 2016; Koo and Ju, 2010; Overmars and Poels, 2015b). For instance, Lim (2012) indicated that e-shop design, informativeness, and functionality are essential customers' motivation factors in online shopping. Properly selected e-shop design, music, and other interactive tools integrating their usability, simplicity, and informativeness create a greater incentive for the user to visit that e-shop more often (Lim, 2013; Lim and Ting, 2012). Various scholars argued that e-shop and product design and the accompanying visual information influence consumer decision-making related to consumers' perception and associations, leading to brand popularity and value (Kahn, 2017). Dong and Gleim's (2018) study showed that visual presentation has the most significant influence on consumer decision-making (Dong and Gleim, 2018). As a result, the various design elements of a product and packaging and their functions increase visual appeal and create a particular functional or sensory value of the brand in terms of credibility, image, popularity, or reputation.

In an e-shop for presenting a spectrum of products, innovative technologies also enable consumers to communicate online to discuss product features and customer reviews. Advances in information and communications technologies also create the preconditions for most online shops to develop e-shop web design by using eye, mouth track techniques' results (Imai et al., 2019; Lin and Yang, 2014) or exploring mobile applications (Davidaviciene et al., 2021; Grewal et al., 2017; Rezaei et al., 2016). That helps observe customers' behavior and propose a unique user experience by forming new visual or sound sensations. In this way, the total proposed value of both e-shop and product combination becomes essential in assessing consumer behavior in online shopping to develop more excellent emotional value through various visualization and audio technologies (Vonkeman et al., 2017).

In recent years, most companies have invested in the visual presentation of products through social networks and e-shop components, such as e-shop design, informativeness, convenience, security, or popularity to create a unique user experience leading to the overall value to the consumer. For instance, Richard et al. (2010) investigated the impact of internet experience (skills, challenge) and web atmospherics (entertainment, structure, informativeness, information content effectiveness) on customer behavior (website involvement, exploratory behavior) and outcomes (website attitudes, pre-purchase evaluations). Research results indicated that internet experience, information content effectiveness, entertainment positively affect exploratory behavior (Richard et al., 2010). Another critical component of product design and packaging is sustainability (Nassar and Tvaronaviciene, 2021; Tesarova et al., 2020). It becomes vital to some customers to choose products and packaging produced in an environmentally friendly way, including organic raw materials and reusable or recyclable products and packaging.

Based on previous scientific studies results (Cao et al., 2018; Davidaviciene et al., 2019; Park et al., 2012), the combination of the e-shop and product components have a decisive impact, especially on those business sectors that produce similar quality products. In this case, a unique proposed value of e-shop and product elements can determine the customer's final decision in online shopping. Scientific literature analysis results show that the most crucial e-shop characteristics are e-shop design, e-shop informativeness, e-shop convenience, e-shop security, and e-shop popularity. From product features' perspectives, scholars mainly focus on product brand, product design and packaging, price, customer reviews, and delivery time (Figure 1). 


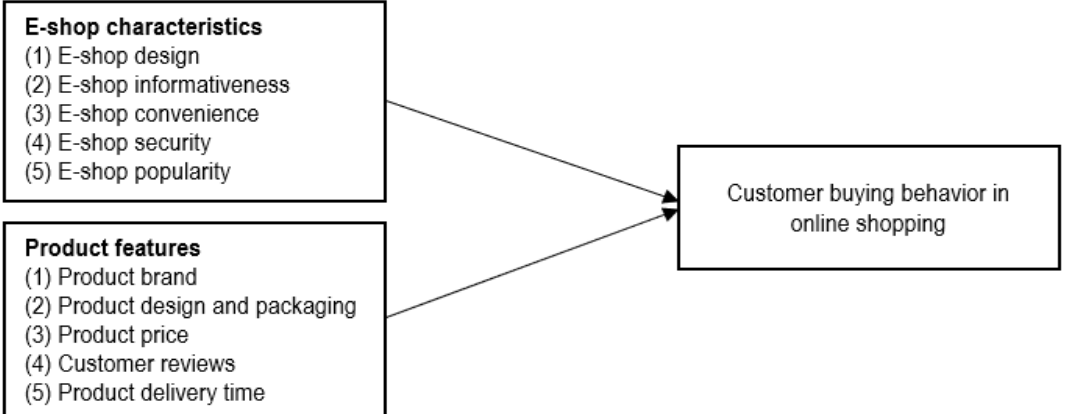

Figure 1. Research model

Sources: developed by the authors based on scientific literature review.

Methodology and research methods. This study aims to identify the key factors influencing potential end-user behavior in online shopping. The case study analysis of Lithuanian consumers was chosen for a comprehensive investigation. A lack of extensive research in the Lithuanian online market leads to identifying which factors are the most significant for consumer decision-making in the electronic space.

Based on the Lithuanian Department of Statistics data on the e-business sector in Lithuania and the number of consumers buying online, the identified survey sample size was 384 potential respondents: consumers who purchase products or services online. Three hundred fifty-six respondents living and shopping online in Lithuania agreed to participate in this investigation. The survey was conducted using a structured questionnaire in 2019, in April-November. The survey was performed by distributing questionnaires online. The research aimed to examine which e-shop characteristics (e-shop design, informativeness, convenience, security, and popularity) and product features (product brand, delivery time, product design and packaging, product price, and customer reviews) most significantly influence Lithuanian consumers to purchase products online.

Thus, 356 respondents participated in the survey having purchasing products or services online experience. During the study, 62 percent of women and 38 percent of men have interviewed. The majority of participating respondents belonged to $18-24$ years (31\%) and $25-30$ years $(30 \%)$ age groups. More than half of the respondents (53\%) have a higher university-level education. The survey results indicated that $60 \%$ of respondents live in big Lithuanian cities, such as Vilnius, Kaunas, Klaipeda (Table 1).

Table 1. Demographic characteristics

\begin{tabular}{clcc}
\hline & Respondents' profile & Frequency & Percent \% \\
\hline \multirow{2}{*}{ Gender } & Female & 222 & 62 \\
& Male & 134 & 38 \\
\hline \multirow{6}{*}{ Age } & $18-24$ & 112 & 31 \\
& $25-30$ & 107 & 30 \\
& $31-39$ & 42 & 12 \\
& $40-50$ & 61 & 17 \\
& 51 and over & 34 & 10 \\
\hline
\end{tabular}

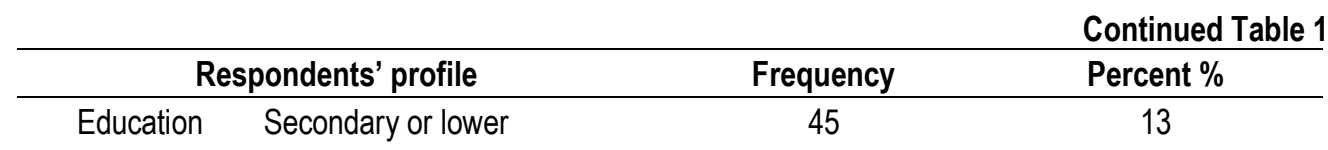




\begin{tabular}{llcc} 
& Vocational & 39 & 11 \\
& Higher non-university-level & 81 & 23 \\
& Higher university-level & 191 & 53 \\
& City & 212 & 60 \\
\multirow{6}{*}{ Location } & Suburb & 69 & 19 \\
& Small town & 51 & 14 \\
& Village & 24 & 7 \\
\hline
\end{tabular}

Sources: developed by the authors.

Results. The study aimed to identify how often consumers visit a physical store compared to online shops. The survey results showed that respondents usually visit the physical store more than three times a week (44\%) or at least once a week (31\%). About 20 percent of respondents visit a one-time physical store every two weeks, and 6 percent of users visit only once a month. When the respondents were asked how often they shop online, $7 \%$ of consumers indicated that they make purchases only online, $13 \%$ more than a few times a month, $25 \%$ once a few months, and the rest part of respondents shop online no more than a few times a year or even less. These research results substantiate that there is a potential online market in Lithuania, although many consumers prefer the traditional way of shopping.

To explore the importance of e-business components on consumers' decision-making processes in the online market, e-shop key evaluation factors such as e-shop design, informativeness, convenience, security, and popularity were identified for further investigation. Respondents were asked to distinguish the most critical elements on a scale [1,5], where 1 is the most significant factor influencing the consumer buying behavior in shopping online, and 5 is the minor significant factor in shopping online. The study results showed that the most crucial factor is e-shop design (38\%) and e-shop security $(20 \%)$. In the second place, e-shop informativeness (44\%) was singled out as a critical factor (Table 2). Appropriately, the study results demonstrate that the main factors affecting customers buying online behavior are e-shop design and e-shop security aspects. The survey also sought to determine the critical factors of product influencing the consumer choice in online shopping: product brand, delivery time, product design and packaging, product price, consumer reviews.

Table 2. E-shop characteristics affecting customer buying behavior in online shopping

\begin{tabular}{lccccc}
\hline \multirow{2}{*}{ Factors } & \multicolumn{5}{c}{ Ranking (Percentage) } \\
\cline { 2 - 6 } & First & Second & Third & Fourth & Fifth \\
\hline E-shop design & 38 & 13 & 15 & 12 & 22 \\
E-shop informativeness & 8 & 44 & 20 & 22 & 6 \\
E-shop convenience & 17 & 17 & 49 & 12 & 5 \\
E-shop security & 20 & 18 & 10 & 42 & 10 \\
E-shop popularity & 17 & 8 & 11 & 11 & 53 \\
\hline
\end{tabular}

Sources: developed by the authors.

Respondents were asked to rank the factors according to significance and impact on consumer shopping behavior online on a scale from 1 to 5 . In this case, 1 is the most significant factor influencing consumer behavior in online shopping, and 5 is the minor significant factor influencing customer decisionmaking in online shopping. The survey results showed that the product design and packaging ( $44 \%$ in the first choice) and product price (26\% in the first choice; $33 \%$ in the second choice) have the most significant influence on their self-determination. Furthermore, the brand of a product has the most negligible effect on consumer choice ( $6 \%$ in the first choice). The survey results indicated that the Lithuanian consumer is 
V., Davidaviciene, J., Raudeliuniene, A., Jonyte-Zemlickiene, M., Tvaronaviciene. Factors Affecting Customer Buying Behavior in Online Shopping

sensitive to the final product price, and this aspect has a substantial impact on product or service choice (Table 3).

Table 3. Influence of product features on customer buying behavior in online shopping

\begin{tabular}{lccccc}
\hline \multirow{2}{*}{ Factors } & \multicolumn{5}{c}{ Ranking (Percentage) } \\
\cline { 2 - 6 } & First & Second & Third & Fourth & Fifth \\
\hline Product brand & 6 & 13 & 10 & 23 & 48 \\
Product delivery time & 13 & 9 & 13 & 42 & 23 \\
Product design and packaging & 44 & 15 & 15 & 9 & 17 \\
Product price & 26 & 33 & 26 & 8 & 7 \\
Customer reviews & 11 & 30 & 37 & 18 & 4 \\
\hline
\end{tabular}

Sources: developed by the authors.

Both correlation and regression analysis were used in the study to check the dependence of the variables. Linear regression analysis was used to compare three principal coefficients: $R^{2}$, ANOVA $p$, and coefficient $\beta$. The dependent variable was the number of purchases in the e-shop (Table 4).

Table 4. E-shop characteristics affecting customer buying behavior in online shopping: regression analysis results

\begin{tabular}{lccc}
\hline \multicolumn{1}{c}{ Variables } & $\mathbf{R}^{2}$ & Coefficient $\boldsymbol{\beta}$ & ANOVA $\mathbf{p}$ \\
\hline E-shop design & 0,36 & 0,19 & 0,003 \\
E-shop informativeness & 0,16 & $-0,18$ & 0,002 \\
E-shop convenience & 0,004 & $-0,02$ & 0,760 \\
E-shop security & 0,26 & 0,12 & 0,048 \\
E-shop popularity & 0,04 & 0,20 & 0,012 \\
\hline
\end{tabular}

Sources: developed by the authors.

The regression analysis results indicated that for customers in online shopping are important two essential variables: e-shop design and e-shop security. Based on the determination coefficient $\left(R^{2}\right)$ outcomes, the factors that determine the consumer's decision to buy in an e-shop are classified according to significance: e-shop design, e-shop security, e-shop informativeness, e-shop popularity, and e-shop convenience. A regression analysis was performed to determine which product features affect consumers' decision to buy in the electronic space. The dependent variable was online shopping, and the independent variable - product features.

The results of the study present that only three product characteristics influence consumers' decisions to buy online. According to the values of the determination coefficient $\left(R^{2}\right)$, the variables were divided in the following way: product design and packaging $\left(R^{2}=0.46\right)$, product price $\left(R^{2}=0.30\right)$, and customer reviews $\left(R^{2}=0.26\right)$. Based on ANOVA p results, the variables were distributed in this way: customer reviews, product price, and product design and packaging. As a result, outcomes illustrate that if the price of a product decreases, customers tend to buy the product online. Besides, shopping is also encouraged by a positive customer review and product design and packaging (Table 5).

Table 5. Influence of product features on customer buying behavior in online shopping: regression analysis results

\begin{tabular}{lccc}
\hline \multicolumn{1}{c}{ Variables } & $\mathbf{R}^{\mathbf{2}}$ & Coefficient $\boldsymbol{\beta}$ & ANOVA p \\
\hline Product design and packaging & 0,46 & 0,07 & 0,026 \\
Customer reviews & 0,26 & 0,08 & 0,037 \\
Product price & 0,30 & $-0,70$ & 0,030
\end{tabular}


V., Davidaviciene, J., Raudeliuniene, A., Jonyte-Zemlickiene, M., Tvaronaviciene. Factors Affecting Customer Buying Behavior in Online Shopping

\begin{tabular}{lccc}
\hline & & & \\
Product brand & 0,01 & 0,01 & 0,065 \\
Product delivery time & 0,003 & $-0,50$ & 0,092 \\
\hline
\end{tabular}

Sources: developed by the authors.

Based on research results, it can be stated that e-shop design and e-shop security are the most crucial aspects for Lithuanian customers to buy online. The most significant factors influencing customer buying behavior in online shopping are product features perspectives: product design and packaging, product price, and customer reviews.

Conclusions. This research presents a Lithuanian case study analysis by investigating e-shop and product characteristics that impact customer buying behavior in online shopping. Based on scientific literature analysis results, the most significant e-shop characteristics are e-shop design, e-shop informativeness, e-shop convenience, e-shop security, and e-shop popularity. Scientists and business practitioners mainly focus on product design and packaging, customer reviews, price, brand, and delivery time from product features' perspectives.

The survey results showed that Lithuanian customers prefer more traditional shopping than online purchases. For instance, consumers usually visit the physical store more than three times a week (44\%) or at least once a week (31\%); in the meantime, only $7 \%$ of respondents indicated that they shop almost online, and $13 \%$ underlined that buying online more than a few times a month. As a result, this study suggests that online purchases in Lithuania are still a growing market. Depending on survey results, the most crucial e-shop characteristics affecting Lithuanian customer buying behavior in online shopping were identified as e-shop design and e-shop security. Meanwhile, the most influencing product features related to customer buying behavior in online shopping were determined product design, packaging, and product price. Correlation and regression analysis proved that for Lithuanian buyers, the most significant factors in online shopping are e-shop design, e-shop security, product design and packaging, product price, and customer reviews. The primary study limitations are related to one case study illustration performed in the Lithuanian online market. Further research could be linked to the expansion of geographical regions with similar economic and cultural environments to examine comprehensive customer buying behavior in online shopping.

Author Contributions: conceptualization, V. D. and A. J-Z.; methodology, V. D. and A. J-Z.; software, A. J-Z.; validation, A. J-Z.; formal analysis, J. R.; investigation, A. J-Z.; resources, M. T.; data curation, A. J-Z.; writing - original draft preparation, J. R.; writing-review and editing, J. R. and M. T.; visualization, J. R.; supervision, V. D. and M. T.

Funding: This research received no external funding.

\section{References}

Agariya, A. K., Johari, A., Sharma, H. K., Chandraul, U. N., \& Singh, D. (2012). The role of packaging in brand communication. International Journal of Scientific \& Engineering Research, 3(2), 1-13. [Google Scholar]

Andryeyeva, N., Nikishyna, O., Burkynskyi, B., Khumarova, N., Laiko, O., \& Tiutiunnyk, H. (2021). Methodology of analysis of the influence of the economic policy of the state on the environment. Insights into Regional Development, 3(2), 198-212. [Google Scholar] [CrossRef]

Bartikowski, B., \& Singh, N. (2014). Should all firms adapt websites to international audiences?. Journal of Business Research, 67(3), 246-252. [Google Scholar] [CrossRef]

Cao, Y., Ajian, H., \& Hong, P. (2018). Post-purchase shipping and customer service experiences in online shopping and their impact on customer satisfaction: an empirical study with comparison. Asia Pacific Journal of Marketing and Logistics. [Google Scholar] [CrossRef]

Cherenkov, V., Sheresheva, M. Starov, S., Gladkikh, I. Tanichev, A., Berezka, S., .. \& Yussuf, A. (2020). Sustainability trends and consumer perceived risks towards private labels. Entrepreneurship and Sustainability Issues, 8(1), 347. [Google Scholar [CrossRef]

Chiabai, A., Platt, S., \& Strielkowski, W. (2014). Eliciting users' preferences for cultural heritage and tourism-related e-services: a tale of three European cities. Tourism Economics, 20(2), 263-277. [Google Scholar] [CrossRef] 


\section{V., Davidaviciene, J., Raudeliuniene, A., Jonyte-Zemlickiene, M., Tvaronaviciene. Factors Affecting Customer Buying Behavior in Online Shopping}

Darsono, J. T., Susana, E., Prihantono, E. Y., \& Eley, S. K. (2019). Strategic Policies for Small and Medium Businesses in marketing through E-commerce. Entrepreneurship and Sustainability Issues, 7(2), 1230. [Google Scholar]

Davidaviciene, V., Raudeliuniene, J., \& VirSilaite, R. (2019). User experience evaluation and creativity stimulation with augmented reality mobile applications. Creativity studies, 12(1), 34-48. [Google Scholar] [CrossRef]

Davidaviciene, V., Raudeliuniene, J., \& VirSilaite, R. (2021). Evaluation of user experience in augmented reality mobile applications. Journal of business economics and management, 22. [Google Scholar] [CrossRef]

Davidaviciene, V., Raudeliuniene, J., Tvaronaviciene, M., \& KauSinis, J. (2019). The importance of security aspects in consumer preferences in electronic environment. Journal of Security \& Sustainability Issues, 8(3). [Google Scholar] [CrossRef]

Dong, R., \& Gleim, M. R. (2018). High or low: The impact of brand logo location on consumers product perceptions. Food Quality and Preference, 69, 28-35. [Google Scholar] [CrossRef]

Grewal, D., Roggeveen, A. L., \& Nordfält, J. (2017). The future of retailing. Journal of retailing, 93(1), 1-6. [Google Scholar] [CrossRef]

Hasan, B. (2016). Perceived irritation in online shopping: The impact of website design characteristics. Computers in Human Behavior, 54, 224-230. [Google Scholar] [CrossRef]

Hussain, S., Ali, S., Ibrahim, M., Noreen, A., \& Ahmad, S. F. (2015). Impact of product packaging on consumer perception and purchase intention. Journal of Marketing and Consumer Research, 10, 1-9. [Google Scholar]

Imai, T., Kang, M. J., \& Camerer, C. F. (2019). When the eyes say buy: visual fixations during hypothetical consumer choice improve prediction of actual purchases. Journal of the Economic Science Association, 5(1), 112-122. [Google Scholar] [CrossRef]

Javaria, K., Masood, O., \& Garcia, F. (2020). Strategies to manage the risks faced by consumers in developing ecommerce. Insights into Regional Development, 2(4), 774-783. [Google Scholar] [CrossRef]

Kahn, B. E. (2017). Using visual design to improve customer perceptions of online assortments. Journal of retailing, 93(1), 2942. [Google Scholar] [CrossRef]

Koo, D. M., \& Ju, S. H. (2010). The interactional effects of atmospherics and perceptual curiosity on emotions and online shopping intention. Computers in human behavior, 26(3), 377-388. [Google Scholar] [CrossRef]

Krishna, A. (2012). An integrative review of sensory marketing: Engaging the senses to affect perception, judgment and behavior. Journal of consumer psychology, 22(3), 332-351. [Google Scholar] [CrossRef]

Lim, W. M. (2013). The effects of web atmospherics on entertainment gratification and web irritation: some empirical evidence from online shopping. Modern Applied Science, 7(12), 15. [Google Scholar] [CrossRef]

Lim, W. M., \& Ting, D. H. (2012). E-shopping: an Analysis of the Technology Acceptance Model. Modern Applied Science, 6(4) 49. [Google Scholar] [CrossRef]

Lin, H. H., \& Yang, S. F. (2014). An eye movement study of attribute framing in online shopping. Journal of Marketing Analytics, 2(2), 72-80. [Google Scholar] [CrossRef]

Nassar, N., \& Tvaronaviciene, M. (2021). A systematic theoretical review on sustainable management for green competitiveness. Insights into Regional Development, 3(2), 267-281. [Google Scholar] [CrossRef]

Overmars, S., \& Poels, K. (2015a). How product representation shapes virtual experiences and re-patronage intentions: the role of mental imagery processing and experiential value. The International Review of Retail, Distribution and Consumer Research, 25(3), 236-259. [Google Scholar] [CrossRef]

Overmars, S., \& Poels, K. (2015b). Online product experiences: The effect of simulating stroking gestures on product understanding and the critical role of user control. Computers in Human Behavior, 51, 272-284. [Google Scholar] [CrossRef]

Park, E. J., Kim, E. Y., Funches, V. M., \& Foxx, W. (2012). Apparel product attributes, web browsing, and e-impulse buying on shopping websites. Journal of Business Research, 65(11), 1583-1589. [Google Scholar] [CrosssRef]

Pieters, R., Wedel, M., \& Batra, R. (2010). The stopping power of advertising: Measures and effects of visual complexity. Journal of Marketing, 74(5), 48-60. [Google Scholar] [CrossRef]

Rahman, M. A., Islam, M. A., Esha, B. H., Sultana, N., \& Chakravorty, S. (2018). Consumer buying behavior towards online shopping: An empirical study on Dhaka city, Bangladesh. Cogent Business \& Management, 5(1), 1514940. [Google Scholar CrossRef[]

Rausser, G., Strielkowski, W., \& Streimikiene, D. (2018). Smart meters and household electricity consumption: A case study in Ireland. Energy \& Environment, 29(1), 131-146. [Google Scholar] [CrossRef]

Rezaei, S., Shahijan, M. K., Amin, M., \& Ismail, W. K. W. (2016). Determinants of app stores continuance behavior: a PLS path modelling approach. Journal of Internet Commerce, 15(4), 408-440. [Google Scholar] [CrossRef]

Richard, M. O., Chebat, J. C., Yang, Z., \& Putrevu, S. (2010). A proposed model of online consumer behavior: Assessing the role of gender. Journal of Business Research, 63(9-10), 926-934. [Google Scholar] [CrossRef]

Rundh, B. (2013). Linking packaging to marketing: how packaging is influencing the marketing strategy. British Food Journal, 115(11), 1547-1563. [Google Scholar] [CrossRef]

Simionescu, M., \& Strielkowski, W. (2017). Brand loyalty and fashion marketing: a case study of Romanian youth. Marketing and Management of Innovations, (1), 25-31. [Google Scholar] [CrossRef]

Spence, C., \& Gallace, A. (2011). Multisensory design: Reaching out to touch the consumer. Psychology \& Marketing, 28(3), 267-308. [Google Scholar] [CrossRef]

Stefko, R., Bacik, R., Fedorko, R., Olearova, M., \& Rigelský, M. (2019). Analysis of consumer preferences related to the use of digital devices in the e-commerce dimension. Entrepreneurship and Sustainability Issues, 7(1), 25. [Google Scholar] [CrossRef] 
Strielkowski, W., Veinbender, T., Tvaronaviciene, M., \& Lace, N. (2020). Economic efficiency and energy security of smart cities. Economic research-Ekonomska istraživanja, 33(1), 788-803. [Google Scholar] [CrossRef]

Tesarova, M., Krmela, A., \& Simberova, I. (2020). Digital support to external sustainability communication in self-adhesive labelling industry. Entrepreneurship and Sustainability Issues, 7(3), 2109. [Google Scholar] [CrossRef]

Vonkeman, C., Verhagen, T., \& Van Dolen, W. (2017). Role of local presence in online impulse buying. Information \& Management, 54(8), 1038-1048. [Google Scholar] [CrossRef]

Wu, A. (2015). Food packaging design and its application in the brand marketing. Carpathian Journal of Food Science \& Technology, 7(3), 5-15. [Google Scholar]

Yu, L., Westland, S., Li, Z., Pan, Q., Shin, M. J., \& Won, S. (2018). The role of individual colour preferences in consumer purchase decisions. Color Research \& Application, 43(2), 258-267. [Google Scholar] [CrossRef]

Віда Давідавічене, Ph.D., Вільнюський технічний університет імені Гедимінаса, Литва

Юргіта Рауделюнієн, Ph.D., Вільнюський технічний університет імені Гедимінаса, Литва

Аквіле Йоните-Земліцкене, Ph.D., Вільнюський технічний університет імені Гедимінаса, Литва

Мануела Тваронавічене, Ph.D., Вільнюський технічний університет імені Гедимінаса, Литва

Онлайн-шоппінг: фактори впливу на поведінку споживачів

Глобалізаційні процеси сприяють прискоренню розвитку інформаційно-комунікаційних технологій, які обумовлюють появу соціальних, економічних та культурних трансформацій, що своєю чергою впливає на потреби та поведінку споживачів в Інтернет-середовищі. 3 огляду на це, організації, в умовах невизначеності та постійної зміни поведінки споживачів, повинні впроваджувати ефективні інструменти створення та промоції унікальної торговельної пропозиції. Авторами наголошено про відсутність загальновизнаного та уніфікованого підходу до визначення та оцінювання факторів, які впливають на поведінку споживачів в Інтернет-середовищі. Таким чином, актуальним є визначення підходу, який найбільш повно враховує всі аспекти поведінки споживачів в Інтернет-середовищі. У ході дослідження проаналізовано теоретичні та практичні підходи щодо оцінювання факторів впливу на рішення споживачів здійснювати купівлю в інтернет-магазині. Метою дослідження є оцінювання індикаторів якості функціонування Інтернет-магазину, як головних факторів впливу на поведінку споживачів в Інтернет-середовищі. Аналіз наукових напрацювань з означеної тематики дослідження дозволив зробити висновок, що дизайн, інфоормаційна цінність, зручність, безпека та популярність Інтернет-магазину є найбільш значущими факторами впливу на поведінку споживачів. 3 іншого боку, науковці та практики приділяють значну увагу характеристикам наявного товару в Інтернет-магазині, а саме: дизайн, упаковка, ціна, бренд, відгуки клієнтів та час виконання замовлення. Інформаційну базу для емпіричного аналізу засновано на даних анкетування споживачів, які проживають у Литовській Республіці. Для досягнення поставленої мети, у роботі застосовано такі методи дослідження як: аналіз наукових напрацювань, опитування (структурована анкета), кореляційний та регресійний аналізи. За результатами опитування встановлено, що литовські споживачі все ще надають перевагу традиційним, аніж Інтернет-магазинам. При цьому Інтернетринок у Литовській Республіці з кожним роком зростає. Результати кореляційного та регресійного аналізів засвідчили, що найбільш значущими факторами впливу на поведінку литовських Інтернет-покупців є: дизайн та безпека інтернет-магазину, упаковка та ціна товару, а також відгуки споживачів.

Ключові слова: поведінка, особливості Інтернет-магазину, характеристики товару, Інтернет-магазин, Литва. 